\title{
Sequence-specific Quantitation of Mutagenic DNA damage via Polymerase Amplification with an Artificial Nucleotide
}

Claudia M.N. Aloisi, Arman Nilforoushan, Nathalie Ziegler, and Shana J. Sturla*

\section{SUPPORTING INFORMATION}

Table of Content:

$\begin{array}{ll}\text { Material and Methods } & \text { S2 }\end{array}$

$\begin{array}{ll}\text { Chemicals } & \text { S2 }\end{array}$

Oligonucleotides and $O^{6}$-CMG plasmid preparation $\quad$ S2

$\begin{array}{ll}\text { Synthesis of artificial triphosphate ExBenziTP } & \text { S2 }\end{array}$

$\begin{array}{ll}\text { General conditions for primer extension assays } & \text { S7 }\end{array}$

$\begin{array}{ll}\text { Steady-state kinetic assay } & \text { S7 }\end{array}$

$\begin{array}{ll}\text { Computational modelling studies } & \text { S8 }\end{array}$

$\begin{array}{ll}\text { Linear amplification of } O^{6}-\mathrm{CMG} \text { DNA } & \text { S9 }\end{array}$

$\begin{array}{ll}\text { Primer extension on } O^{6}-\mathrm{CMG} \text { DNA plasmid } & \mathrm{S} 10\end{array}$

$\begin{array}{ll}\text { DNA hydrolysis and sample preparation } & \mathrm{S} 10\end{array}$

Mass spectrometric method for the detection of ExBenzi nucleoside $\quad$ S11

$\begin{array}{ll}\text { References } & \text { S12 }\end{array}$ 


\section{MATERIAL AND METHODS}

\section{Chemicals}

T4 polynucleotide kinase was purchased from Promega Corp (Madison, USA). Nb.BbvCI and T4 DNA ligase were purchased from NEB (Massachusetts, USA). KlenTaq M747K was purchased from MyPols (Konstanz, Germany). [ $\gamma-$ 32P] ATP was purchased from PerkinElmer Life Sciences (Schwerzenbach, Switzerland). 1-( $\alpha$ )-Chloro-3,5-di- $O$-(ptoluoyl)-2-deoxy-D-ribose was purchased from Carbosynth (Compton, UK). Reagents for solid-phase DNA synthesis and all natural dNTPs were obtained from Link technologies Ltd. (Lanarkshire, Scotland). SYBR gold was purchased from Invitrogen (California, USA). All other reagents were purchased from Sigma Aldrich (Buchs, Switzerland). Thin layer chromatography was carried out with silica gel 60 F254 plates with aluminum backing. A Biotage system with pre-packed SNAP ultra $\mathrm{SiO}_{2}$ cartridges was used for flash chromatography. ${ }^{1} \mathrm{H},{ }^{13} \mathrm{C},{ }^{31} \mathrm{P} \mathrm{NMR}$ spectra were recorded on a Bruker Biospin $400 \mathrm{MHz}$ NMR machine, and chemical shifts are reported in parts per million (ppm, $\delta$ ) relative to the chemical shift of the respective solvent.

\section{Oligonucleotides and $\boldsymbol{O}^{6}$-CMG plasmid preparation}

Oligonucleotides (28 nt template: 5'- ACT CGT CTC CCT ATA GTG AGT CGT ATT A -3'; 23 nt primer for $28 \mathrm{nt}$ template 5'-TAA TAC GAC TCA CTA TAG GGA GA-3'), 5'-6-FAM-labelled oligonucleotides (28 nt template; 23 nt primer; 11 nt primer for plasmid pEGFP-W 5' -CCC GCC CGG GA-3') and $O^{6}$-MeG 28 nt template (5'-ACT CXT CTC CCT ATA GTG AGT CGT ATT A -3'; X= $O^{6}-\mathrm{MeG}$ ) were purchased from Eurogentec (Seraing, Belgium).

An $O^{6}$-CMG $28 \mathrm{nt}$ template (5'- ACT CXT CTC CCT ATA GTG AGT CGT ATT A -3'; X= $O^{6}$-CMG) was synthetized by solid-phase DNA synthesis on a Mermade 4 DNA synthesizer (Bioautomation Corporation; Texas, USA) in trityl-on mode on a $1-\mu \mathrm{mol}$ scale. Universal Q SynBase ${ }^{\mathrm{TM}}$ CPG support columns and natural nucleotide phosphoramidites from Link Technologies Ltd. (Lanarkshire, Scotland, UK) were used. $O^{6}-\mathrm{CMG}$ phospharamidite was kindly donated by Prof. David M. Williams (University of Sheffield, UK).

An $O^{6}$-CMG 20 nt oligonucleotide (5'-TGA GGC AXT CCC GGG CGG GC-3'; X= $O^{6}-\mathrm{CMG}$ ), to be inserted into the plasmid pEGFP-W, was synthetized by solid-phase DNA synthesis on a Mermade 4 DNA synthesizer, and $O^{6}$-CMG phosphoramidite was prepared as previously reported. [1] The $O^{6}$-CMG $20 \mathrm{nt}$ oligonucleotide was inserted into the plasmid as follows: plasmid pEGFP-W was digested by Nb.BbvCI restriction enzyme (NEB, USA) for $1 \mathrm{~h}$ at $37^{\circ} \mathrm{C}$, following the manufacturer recommendations. [2] The resulting nicked plasmid was purified using Monarch Plasmid Miniprep Kit, following the manufacturer protocol. [3] The $O^{6}-\mathrm{CMG} 20 \mathrm{nt}$ oligonucleotide was inserted by combining it with the nicked plasmid in the presence of T4 DNA ligase at room temperature for $18 \mathrm{~h}$ following the manufacturer protocol. [4] The nicking and ligation of the $20 \mathrm{nt}$ oligonucleotide into the linearized plasmid was confirmed by running agorse gels of samples from each step of the plasmid preparation procedure, using reference samples of linear and circular plasmids. The resulting modified plasmid was purified using Monarch Plasmid Miniprep Kit (NEB, USA), following the manufacturer protocol, [3] and its concentration determined by measuring the absorbance at $260 \mathrm{~nm}$, using a NanoDrop Spectrophotometer (Thermofischer, USA).

Synthesis of artificial triphosphates ExBenziTP (4)

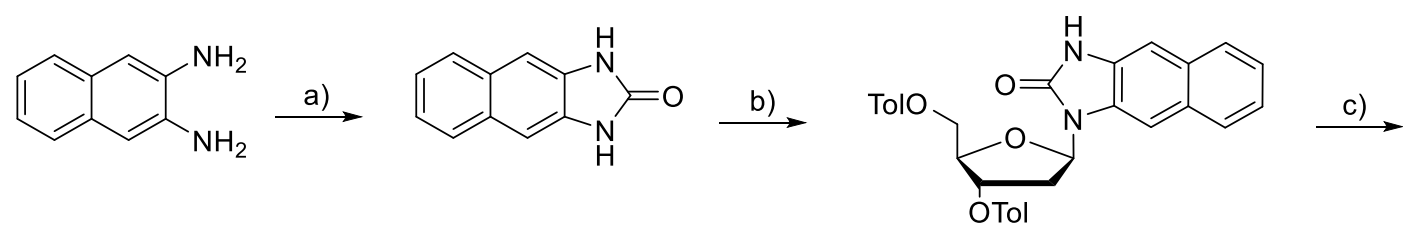

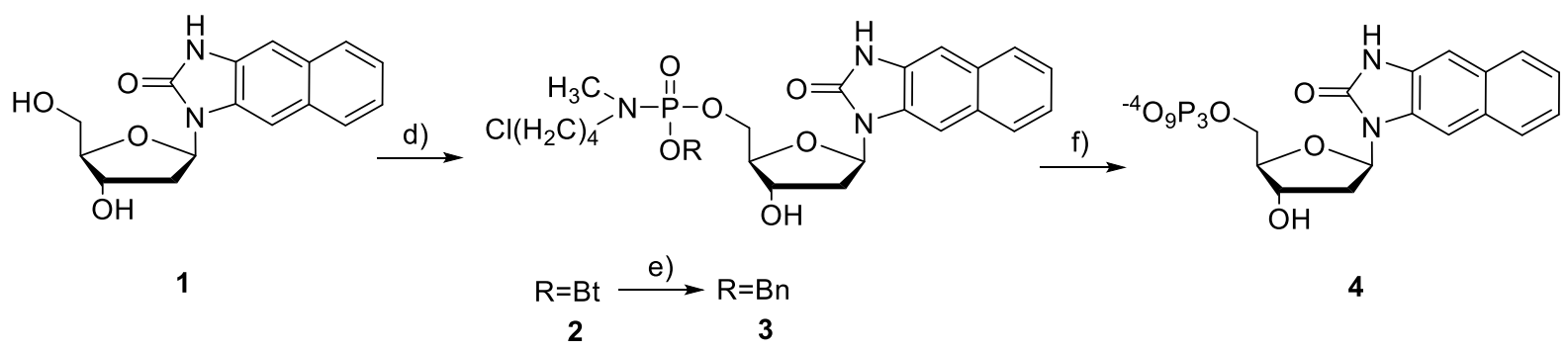

Scheme S1: Synthesis of artificial nucleotide ExBenziTP. a) urea, microwave irradionation. b) (i) NaH, THF, $0^{\circ} \mathrm{C}$; (ii) 1-( $\alpha$ )-chloro-3,5-di- $O$-p-toluoyl-2-deoxy-D-ribose, $25^{\circ} \mathrm{C}$. c) $\mathrm{NaH}, \mathrm{MeOH}: \mathrm{THF}(1: 9), 25^{\circ} \mathrm{C}$.[5] d) (i) (4chlorobutyl)(methyl)phosphoramidic chloride, N-Hydroxybenzotriazole (HOBt), Pyr, THF, $25^{\circ} \mathrm{C}$; (ii) NMI, $\mathrm{THF}, 25^{\circ} \mathrm{C}$. e) $\mathrm{BnOH}, \mathrm{DMAP}, \mathrm{THF}, 25^{\circ} \mathrm{C}$. f) (i) $\mathrm{H}_{2}, 10 \% \mathrm{Pd} / \mathrm{C}, \mathrm{DMF}, 25^{\circ} \mathrm{C}$; (ii) PPi, $25^{\circ} \mathrm{C}$. 
(2R,3S,5R)-(1H-benzo[d][1,2,3]triazol-1-yl $\quad((3-h y d r o x y-5-(2-0 x o-2,3-d i h y d r o-1 H-n a p h t h o[2,3-d]$ imidazol-1yl)tetrahydrofuran-2-yl)methyl) (4-chlorobutyl)(methyl)phosphoramidate (2)

To a solution of $N$-Hydroxybenzotriazole $(0.529 \mathrm{~g}, 3.920 \mathrm{mmol}$, azeotropically dried twice in benzene $)$ in pyridine $(0.25 \mathrm{~mL})$ and THF $(2.5 \mathrm{~mL})$ (4-chlorobutyl)(methyl)phosphoramidic dichloride $(0.466 \mathrm{~g}, 1.961 \mathrm{mmol})$ in THF (1 mL) was added dropwise. The resulting mixture was stirred under nitrogen atmosphere for 4 hours at $25{ }^{\circ} \mathrm{C}$, whereas a white precipitate formed. The white precipitate was filtered and the filtrate was added to a solution in pyridine $(0.5 \mathrm{~mL})$ of $\mathbf{1}$ (0.147 g, $0.490 \mathrm{mmol})$, which was synthesized from 2,3-diaminonaphtalene as previously reported.[5] Then, $N$ methylimidazole (previously dried over MS) $(0.161 \mathrm{~g}, 1.960 \mathrm{mmol})$ was added and the mixture stirred at $25^{\circ} \mathrm{C}$ for 1 hour under nitrogen atmosphere. THF was removed under reduced pressure and the residue was extracted with $\mathrm{CH}_{2} \mathrm{Cl}_{2}$ $(2 \mathrm{x})$ and washed with saturated aqueous $\mathrm{NH}_{4} \mathrm{Cl}(1 \mathrm{x})$ and saturated aqueous $\mathrm{NaHCO}_{3}(1 \mathrm{x})$. Combined organic layers were dried over $\mathrm{Na}_{2} \mathrm{SO}_{4}$, filtered and concentrated. The resulting residue was purified by flash chromatography on a Biotage system using a DCM:MeOH gradient $(3-10 \% \mathrm{MeOH}$ in $15 \mathrm{CV}, 1 \mathrm{CV}=75 \mathrm{~mL})$ the resulting fractions were not pure, so a second purification by flash chromatography was carried out a Biotage system using a DCM:MeOH gradient $(3-8 \%$ $\mathrm{MeOH}$ in $20 \mathrm{CV}, 1 \mathrm{CV}=15 \mathrm{~mL})$ yielding $2(0.060 \mathrm{~g}, 20 \%)$ as a white solid. $\mathrm{Rf}\left(\mathrm{SiO}_{2}, \mathrm{DCM}: \mathrm{MeOH} 97: 3\right)=0.28 ; 1 \mathrm{H}$ NMR $\left(400 \mathrm{MHz}, \mathrm{CD}_{3} \mathrm{OD}\right) \delta 7.92-7.19(\mathrm{~m}, 11 \mathrm{H}), 6.35-6.31(\mathrm{~m}, 1 \mathrm{H}), 4.66(\mathrm{dt}, \mathrm{J}=11.8,5.1 \mathrm{~Hz}, 1 \mathrm{H}), 4.55-4.47(\mathrm{~m}$, $2 \mathrm{H}), 4.11-4.08(\mathrm{~m}, 1 \mathrm{H}), 3.27(\mathrm{dt}, \mathrm{J}=3.3,1.6 \mathrm{~Hz}, 3 \mathrm{H}), 3.16-3.09(\mathrm{~m}, 1 \mathrm{H}), 3.03-2.91(\mathrm{~m}, 2 \mathrm{H}), 2.76-2.69(\mathrm{~m}, 3 \mathrm{H})$, $2.30-2.20(\mathrm{~m}, 1 \mathrm{H}), 1.45-1.33(\mathrm{~m}, 4 \mathrm{H}) ; 13 \mathrm{C} \mathrm{NMR}\left(100 \mathrm{MHz}, \mathrm{CD}_{3} \mathrm{OD}\right) \delta 156.59,144.28,131.52,131.06,130.55$, $130.38,130.07,129.87,129.46,129.30,128.58,128.01,126.61,125.40,125.02,120.48,110.96,107.13,106.15,85.14$, 83.81, 71.48, 69.60, 68.86, 45.01, 37.36, 33.93, 30.31, 25.90; 31P NMR (160 MHz, CD3OD) relative to phosphoric acidstandard: $\delta 13.07(\mathrm{~d}, \mathrm{~J}=14.6 \mathrm{~Hz}, 1 \mathrm{P})$; HRMS (ESI) calculated for C27H30ClN6O6P: [M+Na+] m/z 623.1545, found: 623.1548 .

${ }^{1} H$ NMR (2R,3S,5R)-(1H-benzo[d] [1,2,3]triazol-1-yl ((3-hydroxy-5-(2-oxo-2,3-dihydro-1H-naphtho[2,3-d]imidazol-1yl)tetrahydrofuran-2-yl)methyl) (4-chlorobutyl)(methyl)phosphoramidate (2) $\left(\mathrm{CD}_{3} \mathrm{OD}\right)$

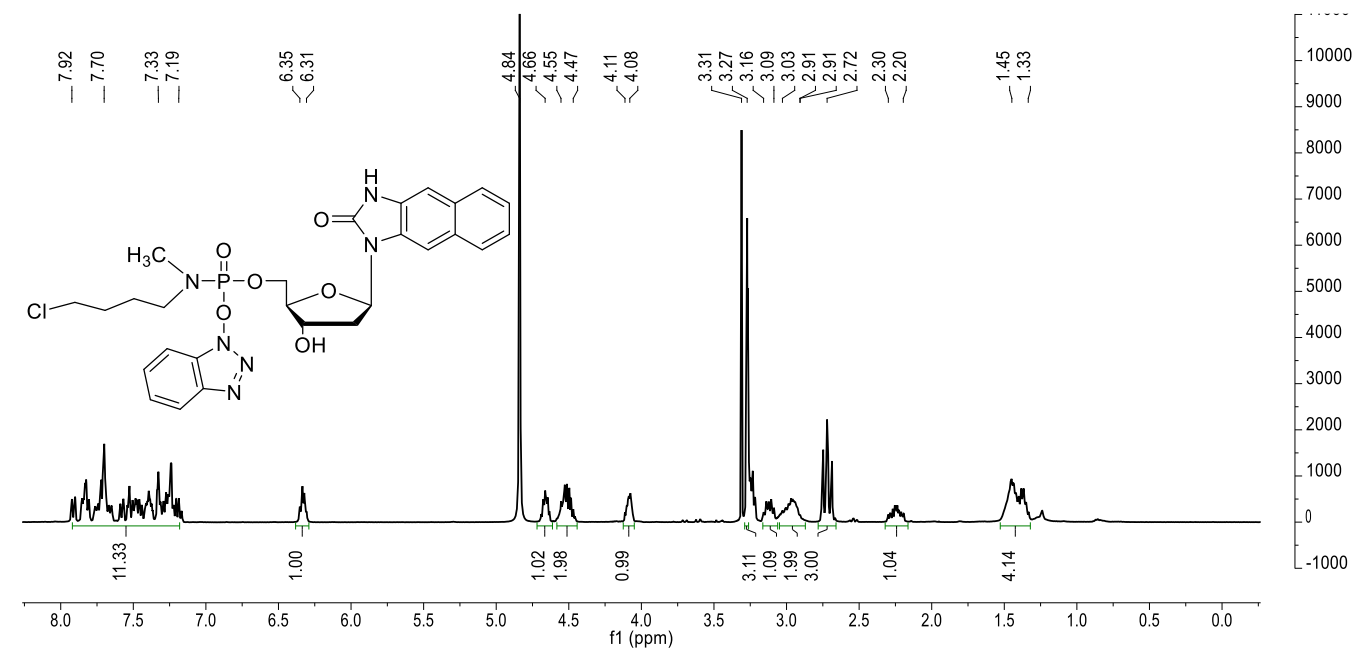

${ }^{13}$ C NMR (2R,3S,5R)-(1H-benzo[d][1,2,3]triazol-1-yl ((3-hydroxy-5-(2-oxo-2,3-dihydro-1H-naphtho[2,3-d]imidazol1-yl)tetrahydrofuran-2-yl)methyl) (4-chlorobutyl)(methyl)phosphoramidate (2) $\left(\mathrm{CD}_{3} \mathrm{OD}\right)$
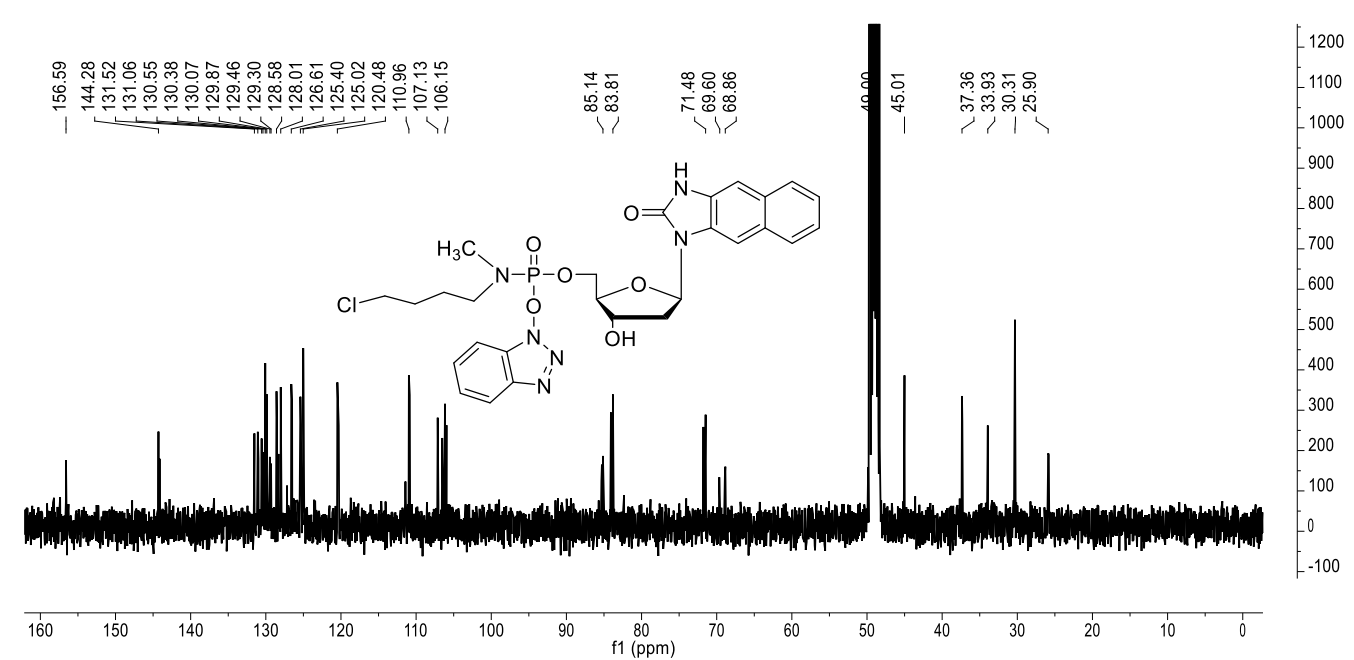
${ }^{31} P$ NMR (2R,3S,5R)-(1H-benzo[d][1,2,3]triazol-1-yl ((3-hydroxy-5-(2-oxo-2,3-dihydro-1H-naphtho[2,3-d] imidazol1-yl)tetrahydrofuran-2-yl)methyl) (4-chlorobutyl)(methyl)phosphoramidate (2) (CD $\mathrm{CDD}_{3} \mathrm{O}$

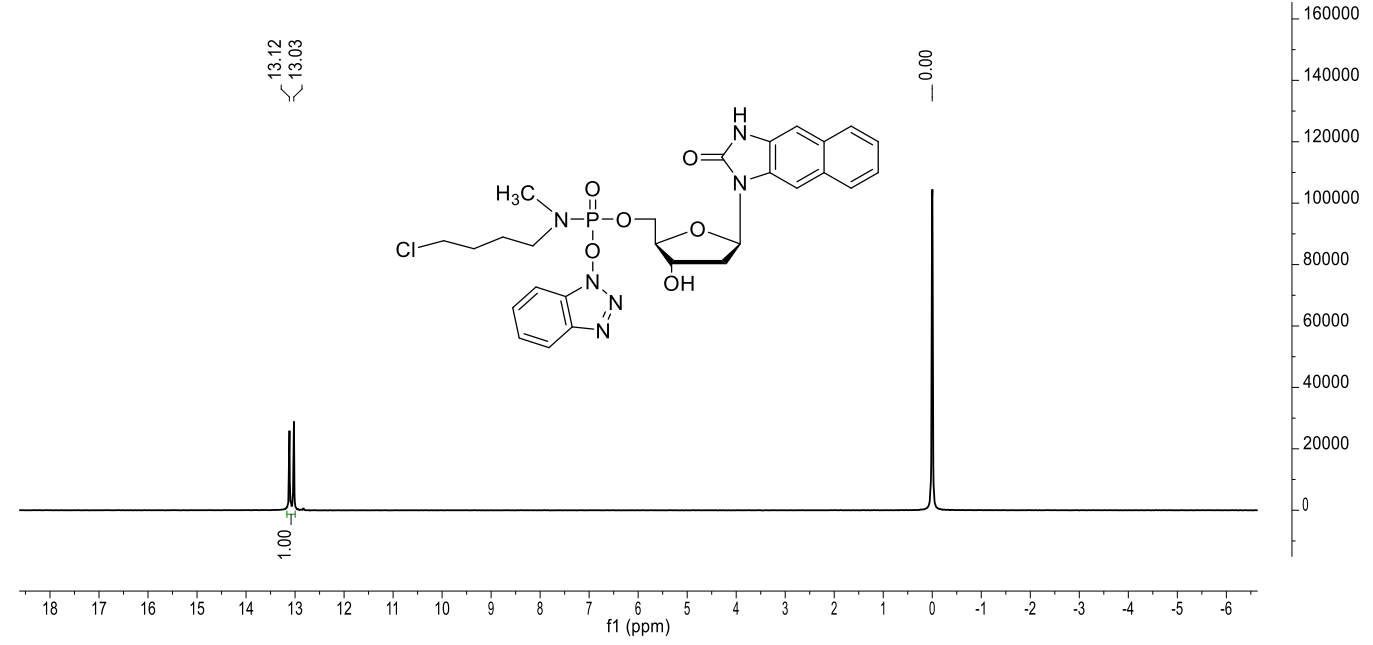

(2R,3S,5R)benzyl ((3-hydroxy-5-(2-oxo-2,3-dihydro-1H-naphtho[2,3-d]imidazol-1-yl)tetrahydrofuran-2yl)methyl) (4-chlorobutyl)(methyl)phosphoramidate (3)

Compound 2 (0.060 g, $0.102 \mathrm{mmol})$ was dissolved in THF $(1 \mathrm{~mL})$ and Benzyl alcohol $(0.552 \mathrm{~g}, 5.111 \mathrm{mmol})$ was added in one portion. To the solution, 4-Dimethylaminopyridine $(0.050 \mathrm{~g}, 0.409 \mathrm{mmol})$ was added and the reaction was stirred under nitrogen atmosphere at $25{ }^{\circ} \mathrm{C}$ for 96 hours. The reaction was concentrated under reduced pressure and purified by flash chromatography on a Biotage system using a DCM:MeOH gradient $(0-10 \% \mathrm{MeOH}$ over $30 \mathrm{CV}, 1 \mathrm{CV}$ $=15 \mathrm{ml})$, yielding product $3(0.030 \mathrm{~g}, 52 \%)$ as a white foamy solid. $\mathrm{Rf}\left(\mathrm{SiO}_{2}, \mathrm{DCM}: \mathrm{MeOH} 95: 5\right)=0.27 ; 1 \mathrm{H} \mathrm{NMR}(400$ $\left.\mathrm{MHz}, \mathrm{CD}_{3} \mathrm{OD}\right) \delta 7.85(\mathrm{~d}, \mathrm{~J}=6.2 \mathrm{~Hz}, 0.5 \mathrm{H}), 7.76(\mathrm{~d}, \mathrm{~J}=7.8 \mathrm{~Hz}, 1.5 \mathrm{H}), 7.61(\mathrm{~d}, \mathrm{~J}=5.2 \mathrm{~Hz}, 1 \mathrm{H}), 7.39-7.20(\mathrm{~m}, 8 \mathrm{H})$, $6.35(\mathrm{t}, \mathrm{J}=7.3 \mathrm{~Hz}, 1 \mathrm{H}), 5.10-5.00(\mathrm{~m}, 1 \mathrm{H}), 4.95(\mathrm{~d}, \mathrm{~J}=8.0 \mathrm{~Hz}, 1 \mathrm{H}), 4.70-4.59(\mathrm{~m}, 1 \mathrm{H}), 4.31-4.17(\mathrm{~m}, 2 \mathrm{H}), 4.09-$ $4.05(\mathrm{~m}, 1 \mathrm{H}), 3.09-2.85(\mathrm{~m}, 3 \mathrm{H}), 2.54(\mathrm{t}, \mathrm{J}=10.2 \mathrm{~Hz}, 3 \mathrm{H}), 2.27-2.15(\mathrm{~m}, 1 \mathrm{H}), 1.50-1.37(\mathrm{~m}, 4 \mathrm{H}) ; 13 \mathrm{C}$ NMR $(100$ $\mathrm{MHz}, \mathrm{CD} 3 \mathrm{OD}) \delta 156.56,156.54,137.56,131.51,131.04,130.81,130.37,129.64,129.56,129.42,129.25,128.97$, $128.65,128.02,107.34,106.90,106.08,85.69,84.02,72.10,71.61,69.40,67.46,66.53,49.00,45.22,37.34,33.56$, 30.61, 26.04; 31P NMR (160 MHz, $\left.\mathrm{CD}_{3} \mathrm{OD}\right)$ relative to phosphoric acid standard: $\delta 11.69$ (d, J = 69.5 Hz, 1P); HRMS (ESI) calculated for $\mathrm{C}_{28} \mathrm{H}_{33} \mathrm{ClN}_{3} \mathrm{O}_{6} \mathrm{P}:[\mathrm{M}+\mathrm{Na}+] \mathrm{m} / \mathrm{z} 596.1688$, found: 596.1686 .

${ }^{1} H$ NMR (2R,3S,5R)benzyl ((3-hydroxy-5-(2-oxo-2,3-dihydro-1H-naphtho[2,3-d]imidazol-1-yl)tetrahydrofuran-2yl)methyl) (4-chlorobutyl)(methyl)phosphoramidate (3) $\left(\mathrm{CD}_{3} \mathrm{OD}\right)$

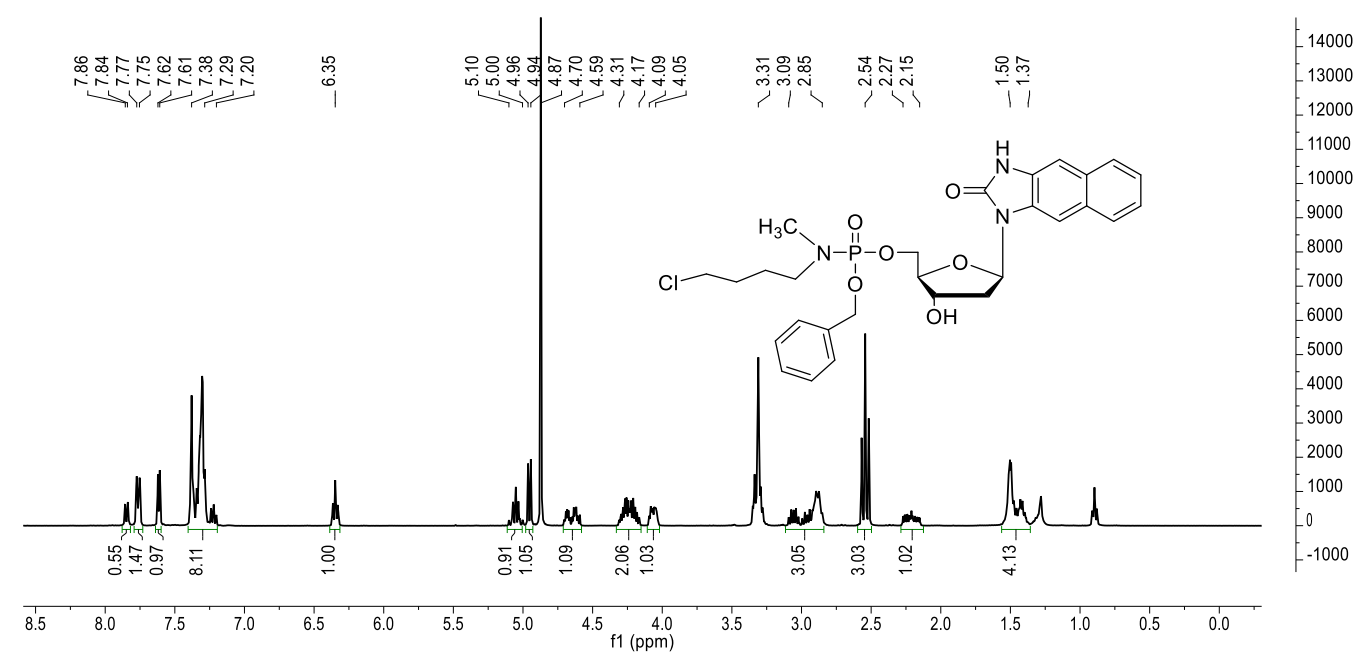

${ }^{13}$ C NMR (2R,3S,5R)benzyl ((3-hydroxy-5-(2-oxo-2,3-dihydro-1H-naphtho[2,3-d]imidazol-1-yl)tetrahydrofuran-2yl)methyl) (4-chlorobutyl)(methyl)phosphoramidate (3) $\left(\mathrm{CD}_{3} \mathrm{OD}\right)$ 


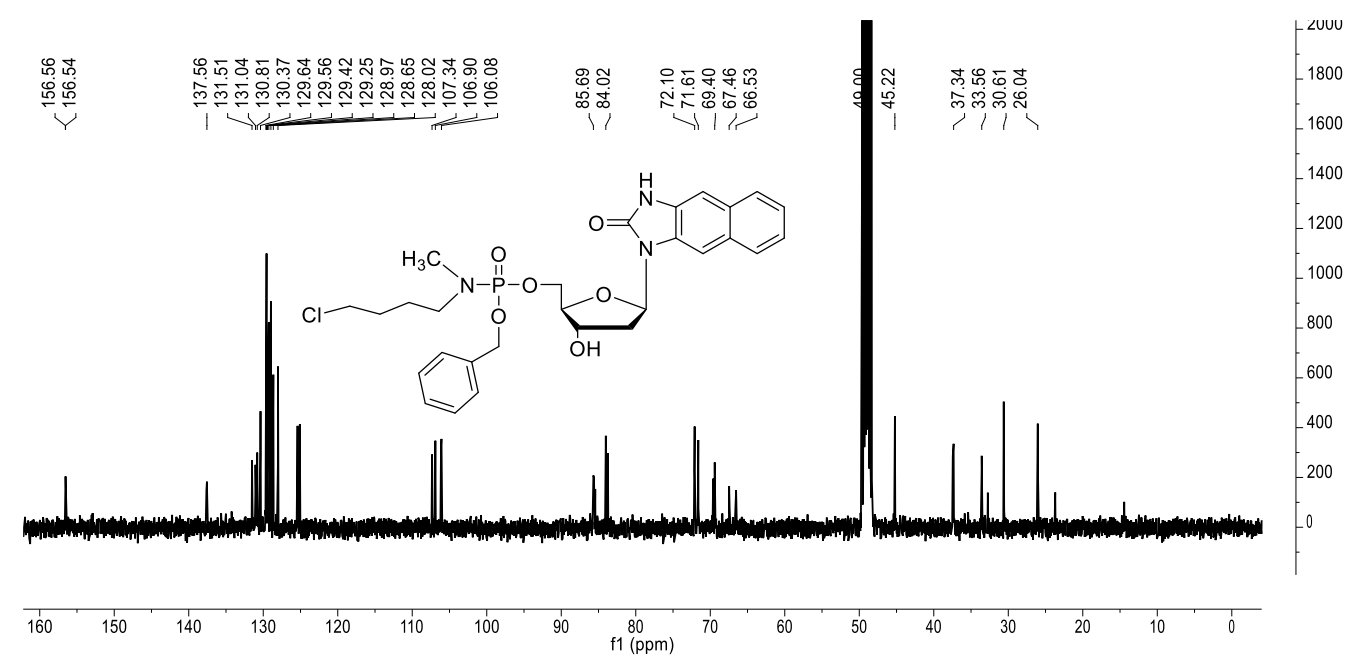

${ }^{31}$ P NMR (2R,3S,5R)benzyl ((3-hydroxy-5-(2-oxo-2,3-dihydro-1H-naphtho[2,3-d]imidazol-1-yl)tetrahydrofuran-2yl)methyl) (4-chlorobutyl)(methyl)phosphoramidate (3) $\left(\mathrm{CD}_{3} \mathrm{OD}\right)$

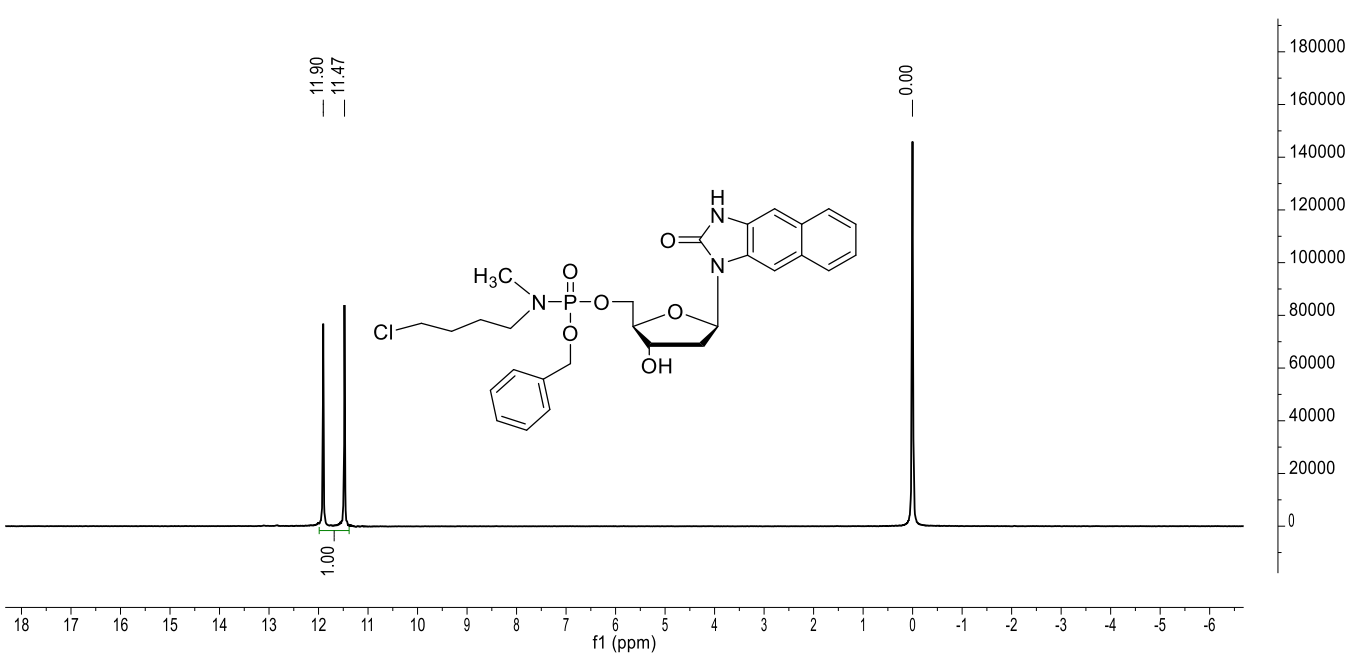

(2R,3S,5R)-(3-hydroxy-5-(2-oxo-2,3-dihydro-1H-naphtho[2,3-d]imidazol-1-yl)tetrahydrofuran-2-yl)methyl triphosphate (4)

Compound 3 (0.030 g, $0.052 \mathrm{mmol})$ was dissolved in anhydrous DMF (2 mL) and given to a flask set under $\mathrm{H}_{2}$. A tip of palladium catalyst $(10 \% \mathrm{Pd} / \mathrm{C})$ was added and the mixture was stirred under an $\mathrm{H}_{2}$ atmosphere at $25^{\circ} \mathrm{C}$ for 2 hours. The reaction mixture was filtered through a $0.45 \mu \mathrm{m}$ syringe filter to remove the catalyst. Tris(tetra-n-butylammonium) hydrogen pyrophosphate $(0.029 \mathrm{~g}, 0.052 \mathrm{mmol})$ was added to the filtrate, and the mixture was stirred for 4 hours at 25 ${ }^{\circ} \mathrm{C}$ under nitrogen atmosphere. DMF was removed under reduced pressure and residual was diluted in $1 \mathrm{~mL}$ MilliQ water. The resulting solution was purified twice by reverse-phase HPLC: first on a Phenomenex LUNA C18 column $(250 \times 10 \mathrm{~mm})$ with an acetonitrile in $50 \mathrm{mM}$ TEAA $(\mathrm{pH} 7)$ gradient $(2-60 \%$ in $25 \mathrm{~min}$, flow rate $2 \mathrm{ml} / \mathrm{min})$; the collected fractions were subjected to a second purification using the same column and solvents $(20-60 \%$ ACN in $50 \mathrm{mM}$ TEAA $(\mathrm{pH} 7)$ in $25 \mathrm{~min})$ yielding product $4(0.006 \mathrm{~g}, 21 \%)$ with triethylammonium (TEA+) as counter ion. To exchange the counter ion to the sodiated form, product $4(0.006 \mathrm{~g}, 0.011 \mathrm{mmol})$ was dissolved in $0.25 \mathrm{~mL}$ MilliQ water, then $\mathrm{NaClO}_{4}$ $(0.040 \mathrm{~g}, 0.330 \mathrm{mmol})$ was added and the mixture was stirred for 2 hours at $25^{\circ} \mathrm{C}$. Then, Acetone $(1.75 \mathrm{~mL})$ was added and the mixture centrifuged for 3 minutes at 14'000 g. The supernatant was carefully discarded and the pellet was dissolved in $0.5 \mathrm{~mL}$ water and lyophilized to give final sodiated triphosphate $4(0.0012 \mathrm{~g})$. $1 \mathrm{H} \mathrm{NMR}\left(400 \mathrm{MHz}, \mathrm{D}_{2} \mathrm{O}\right) \delta$ $8.18-8.13(\mathrm{~m}, 1 \mathrm{H}), 7.98-7.87(\mathrm{~m}, 2 \mathrm{H}), 7.62(\mathrm{~s}, 1 \mathrm{H}), 7.53-7.49(\mathrm{~m}, 2 \mathrm{H}), 6.45-6.40(\mathrm{~m}, 1 \mathrm{H}), 4.91(\mathrm{dd}, \mathrm{J}=7.3,3.7$ $\mathrm{Hz}, 1 \mathrm{H}), 4.43-4.22(\mathrm{~m}, 3 \mathrm{H}), 3.08(\mathrm{dt}, \mathrm{J}=16.2,8.2 \mathrm{~Hz}, 1 \mathrm{H}), 2.32-2.26(\mathrm{~m}, 1 \mathrm{H}) ; 13 \mathrm{C}$ NMR $\left(100 \mathrm{MHz}, \mathrm{D}_{2} \mathrm{O}\right.$, referenced to acetone) $\delta 156.38,130.08,129.82,128.87,128.49,127.25,125.19,124.87,107.51,106.07,84.96,82.88,70.83,35.46$; 31P NMR (160 MHz, $\left.\mathrm{D}_{2} \mathrm{O}\right)$ relative to phosphoric acid standard: $\delta-10.83(\mathrm{~d}, \mathrm{~J}=19.8 \mathrm{~Hz}, 1 \mathrm{P}),-11.34(\mathrm{~d}, \mathrm{~J}=20.1 \mathrm{~Hz}$, 1P), -23.20 (t, J = 20.5 Hz, 1P); HRMS (ESI) calculated for $\mathrm{C}_{16} \mathrm{H}_{19} \mathrm{~N}_{2} \mathrm{O}_{13} \mathrm{P}_{3}$ : [M-H+] m/z 539.0016, found: 539.0024 . 
${ }^{1} H$ NMR (2R,3S,5R)-(3-hydroxy-5-(2-oxo-2,3-dihydro-1H-naphtho[2,3-d] imidazol-1-yl)tetrahydrofuran-2-yl)methyl triphosphate (4) $\left(\mathrm{D}_{2} \mathrm{O}\right)$

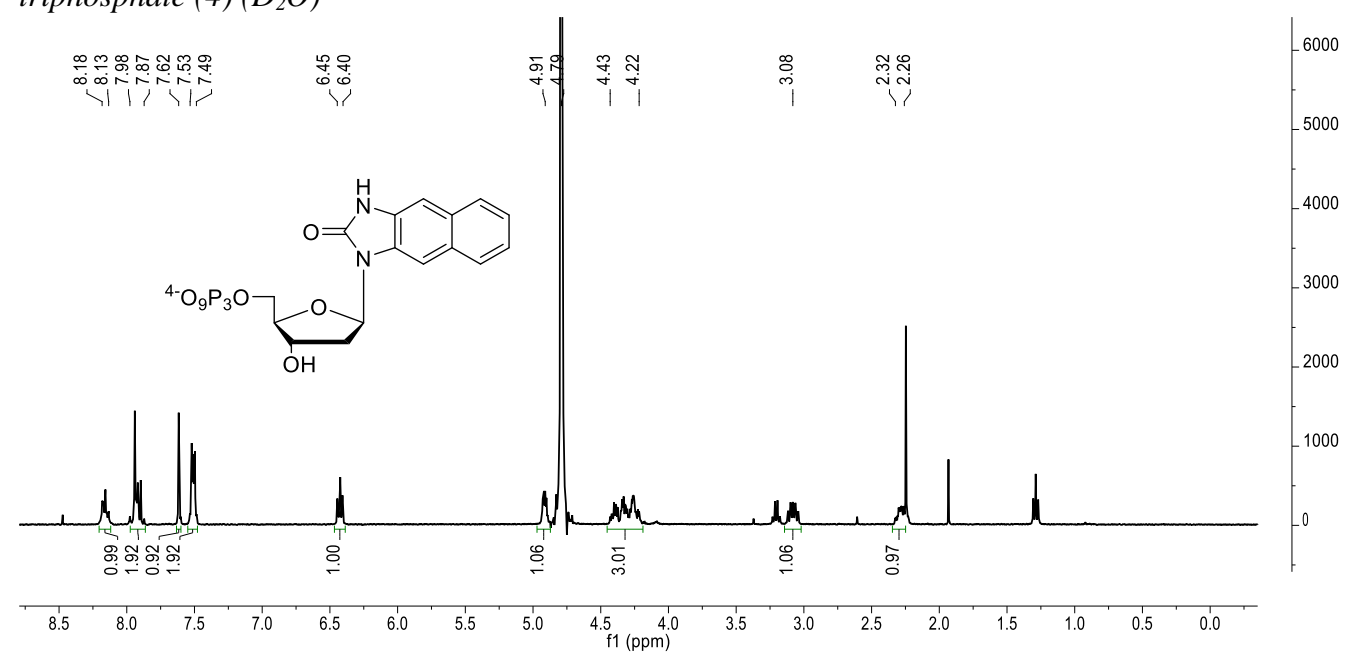

${ }^{13}$ C NMR (2R,3S,5R)-(3-hydroxy-5-(2-oxo-2,3-dihydro-1H-naphtho[2,3-d]imidazol-1-yl)tetrahydrofuran-2-yl)methyl triphosphate (4) $\left(\mathrm{D}_{2} \mathrm{O}\right)$
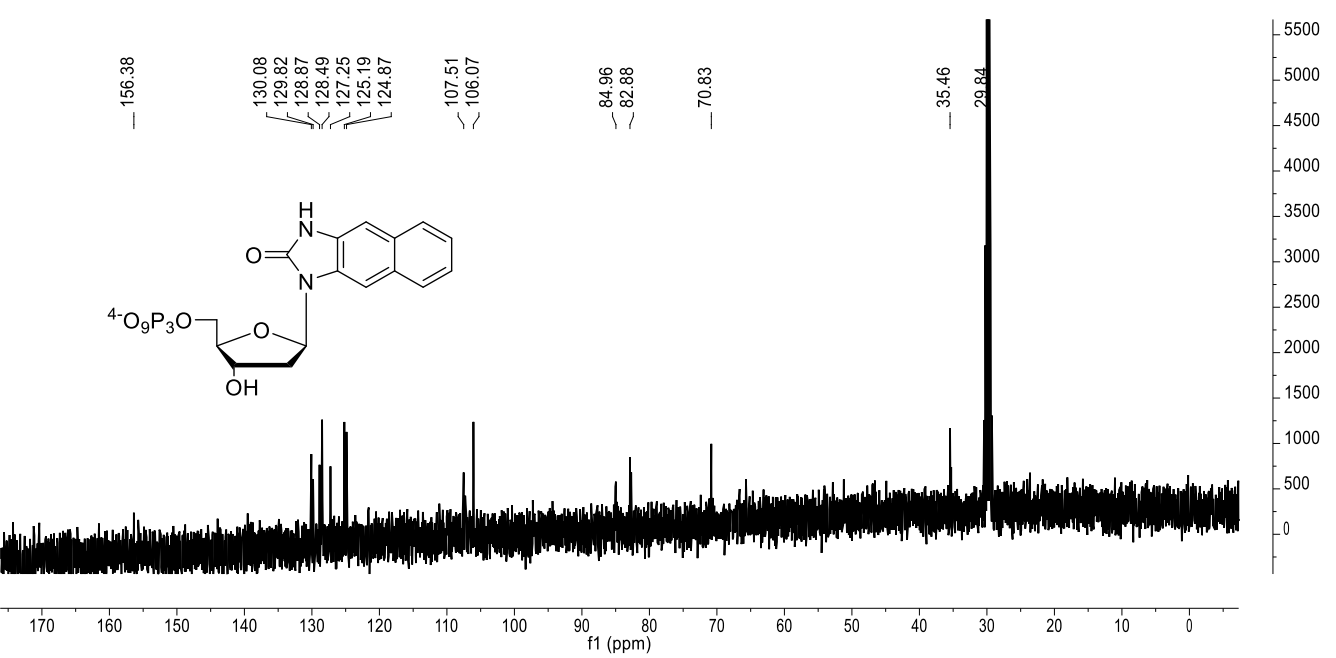

${ }^{31} \mathrm{P}$ NMR (2R,3S,5R)-(3-hydroxy-5-(2-oxo-2,3-dihydro-1H-naphtho[2,3-d]imidazol-1-yl)tetrahydrofuran-2-yl)methyl triphosphate (4) $\left(\mathrm{D}_{2} \mathrm{O}\right)$

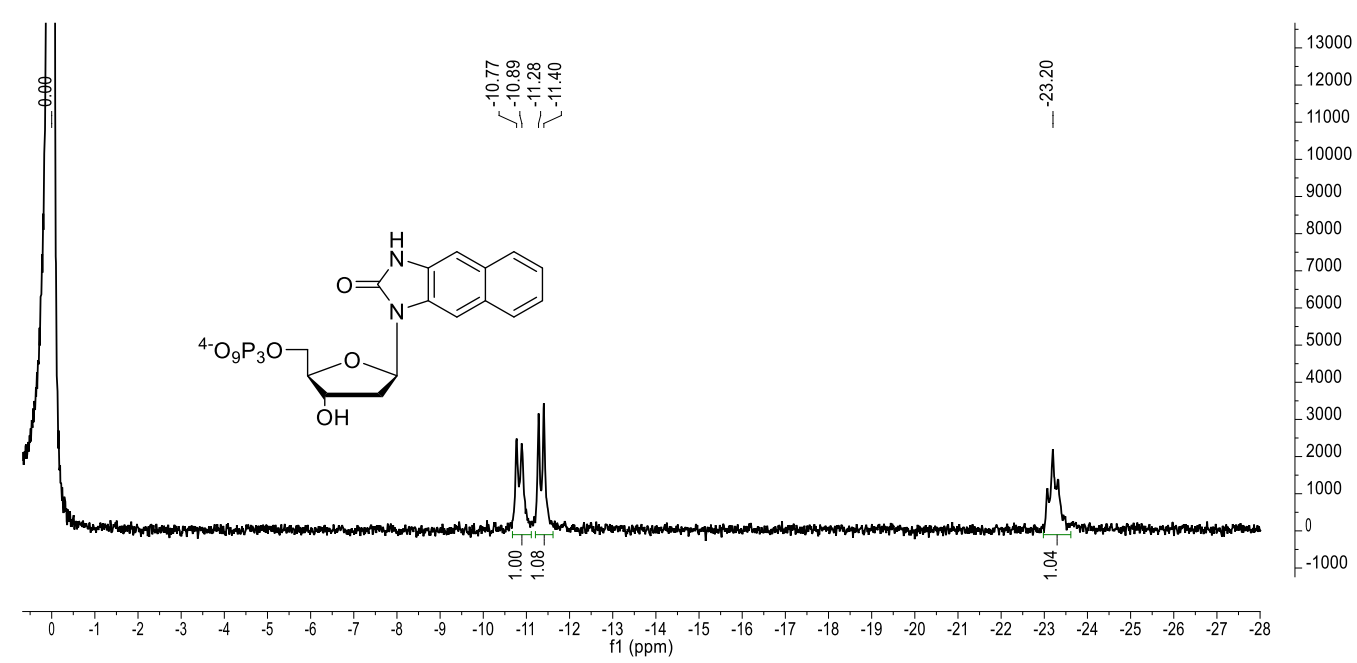




\section{General conditions for primer extension assays}

Radioactive labelling of the $23 \mathrm{nt}$ primer strand at the 5 ' end was carried out using T4 polynucleotide kinase and $[\gamma$ ${ }^{32} \mathrm{P}$ ] ATP and following the manufacturer protocol.[6] The labeled primer strand was annealed to either the unmodified $28 \mathrm{nt}$ or the $O^{6}-\mathrm{CMG} 28 \mathrm{nt}$ template by heating at $95^{\circ} \mathrm{C}$ for $5 \mathrm{~min}$ a mixture of primer:template $(1.5: 1)$ and slow cooling down overnight. Standard primer extension reactions $(10 \mu \mathrm{l})$ contained $1 \times$ KTQ reaction buffer, $5 \mathrm{nM}$ KlenTaq M747K, $15 \mathrm{nM}$ DNA (15 nM primer and $22.5 \mathrm{nM}$ template), and $10 \mu \mathrm{M}$ dNTPs. In full-length DNA synthesis experiments, reactions contained all four natural dNTPs $(10 \mu \mathrm{M}$ total) with or without either BenziTP or ExBenziTP (10 $\mu \mathrm{M})$. Primer/template, nucleotides and DNA polymerase were incubated at $55^{\circ} \mathrm{C}$ for $10 \mathrm{~min}$. $1 \times \mathrm{KTQ}$ reaction buffer contained $50 \mathrm{mM}$ Tris- $\mathrm{HCl}(\mathrm{pH} 9.2), 16 \mathrm{mM}\left(\mathrm{NH}_{4}\right)_{2} \mathrm{SO}_{4}, 2.5 \mathrm{mM} \mathrm{MgCl}_{2}$, and $0.1 \%$ Tween 20. Reactions were quenched by adding $20 \mu \mathrm{l}$ PAGE gel loading buffer $(80 \%$ formamide, $20 \mathrm{mM}$ EDTA, $0.05 \%$ bromophenol blue, $0.05 \%$ xylene cyanole $\mathrm{FF})$. Reaction mixtures $(4 \mu \mathrm{L})$ were loaded onto $15 \%$ polyacrylamide / $7 \mathrm{M}$ urea gel, which was previously equilibrated for $30 \mathrm{~min}$ with $1 \mathrm{x}$ TBE (100 mM Tris base, $100 \mathrm{mM}$ boric acid, $2 \mathrm{mM}$ EDTA) and run for 3-4 h at 1500 V. Extension products were visualized by autoradiography using a phosphorimager (BioRad, Hercules, CA, USA) by incubating the gel containing radioactive products on a phosphorimaging screen for 1-2 $\mathrm{h}$, according to the strength of $\gamma$-activity. Product band intensities were quantified by densitometry using Quantity One Software (BioRad).
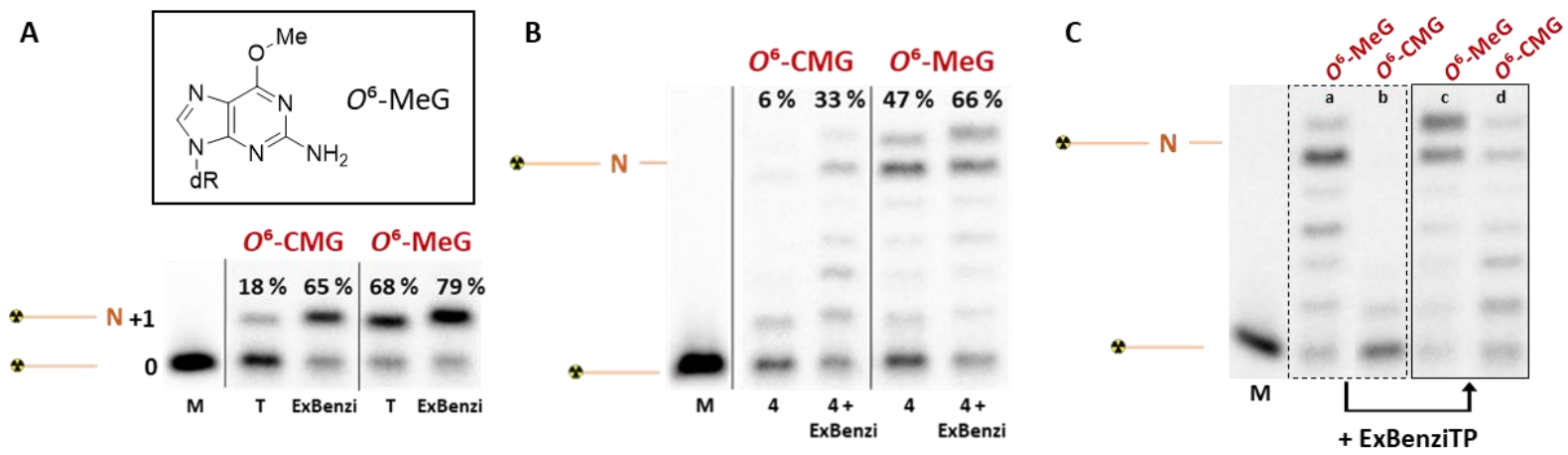

Figure S1 Single nucleotide-incorporation opposite $\boldsymbol{O}^{6}$-MeG and full-length synthesis. (A) Structure of $O^{6}-\mathrm{MeG}$ base (box) and result of single nucleotide-incorporation of T and ExBenzi opposite $\mathrm{X}=O^{6}-\mathrm{CMG}$ or $O^{6}-\mathrm{MeG}$, catalyzed by KlenTaq $\mathrm{M} 747 \mathrm{~K}$, analyzed on denaturing polyacrylamide gels and visualized by autoradiography $(\mathrm{M}=$ marker lane with $23 \mathrm{nt}$ primer). The incorporation fo $\mathrm{T}$ and ExBenzi opposite $O^{6}-\mathrm{MeG}$ are similar (68\% and $79 \%$ respectively) (B) Full-length extension of DNA primer on $O^{6}-\mathrm{CMG}$ or $O^{6}-\mathrm{MeG}$ DNA template, in the presence of all four natural dNTPS (4), and ExBenziTP ( 4 + ExBenziTP). Reactions were catalyzed by KlenTaq M747K for 5 min, analyzed on denaturing polyacrylamide gels and visualized by autoradiography $\left(\mathrm{M}=\right.$ marker lane with $23 \mathrm{nt}$ primer). DNA synthesis past $O^{6}$ CMG by Klen-Taq M7474K is low in the presence of natural dNTPs (6\%, under reported conditions). When ExBenzi is added, the primer is extended past $O^{6}-\mathrm{MeG} 47 \%$ ). (C) Full-length extension of DNA primer on $O^{6}-\mathrm{MeG}(\mathrm{a}, \mathrm{c})$ or $O^{6}-$ CMG (b, d) DNA template catalyzed by KlenTaq M747K for $10 \mathrm{~min}$ in the presence of all four natural dNTPs. Reactions $\mathbf{a}$ and $\mathbf{b}$ were stopped after $10 \mathrm{~min}$. ExBenziTP was added to reactions $\mathbf{c}$ and $\mathbf{d}$ and allowed to react for additional 10 min. All reactions were analyzed on denaturing polyacrylamide gels and visualized by autoradiography $(\mathrm{M}=$ marker lane with $23 \mathrm{nt}$ primer).

\section{Steady-state kinetic assays}

Steady-state kinetics parameters for single nucleotide incorporation by DNA polymerase KlenTaq M747K were determined under single completed hit conditions.[7-8] For varying dNTP concentrations, the quantity of $n+1$ product formed by performing the reaction at $55{ }^{\circ} \mathrm{C}$ was measured. Reaction mixtures included $5 \mathrm{nM}$ KlenTaq M747K, $100 \mathrm{nM}$ primer, $150 \mathrm{nM}$ template, and 1× KTQ reaction buffer. Reactions were initiated by adding pre-warmed enzyme and DNA mix to pre-warmed dNTPs. Reactions were quenched by adding PAGE loading buffer. Reaction mixtures $(4 \mu \mathrm{L})$ were separated on a $15 \%$ polyacrylamide / $7 \mathrm{M}$ urea denaturing gel, visualized by autoradiography, and quantified with Quantity One Software (BioRad). To obtain kinetic parameters $v_{\max }, K_{M}$ and $k_{c a t}$, the intensities of $n+1$ bands (quantified on the Quantity One Software, BioRad) were fit to a Michaelis-Menten hyperbola curve using GraphPad Prism 8 (GraphPad Software). Reactions were performed at least in triplicate and the averaged Michaelis-Menten curves are shown in S1. For $K_{M}$ values, means ( \pm standard deviations) are reported (Table 1 and $\mathrm{S} 1$ ). 

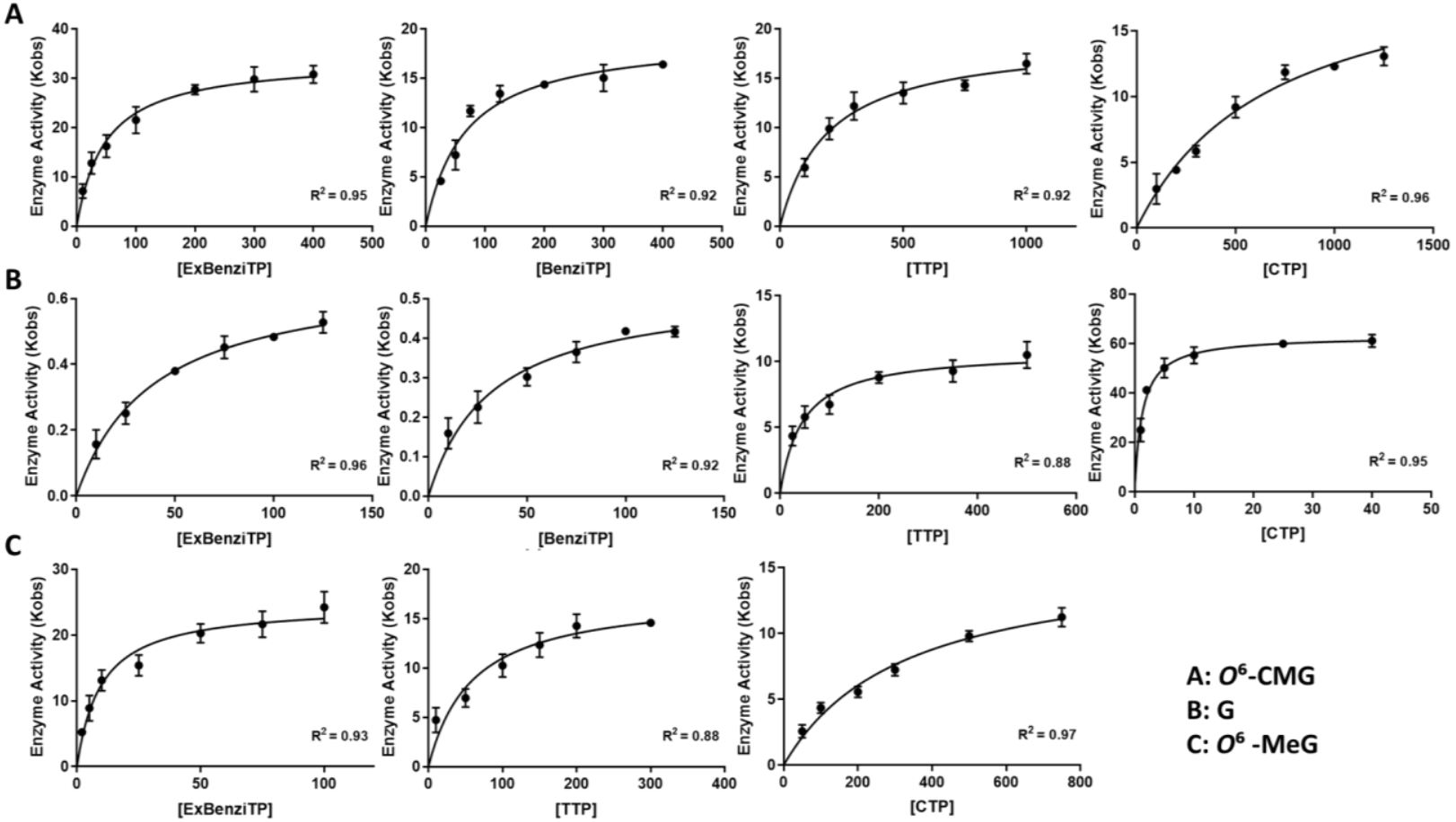

\section{A: $0^{6}$-CMG \\ B: $\mathbf{G}$ \\ C: $O^{6}-\mathrm{MeG}$}

Figures S2 Michaelis-Menten hyperbola curves. The observed rate constants (Kobs) of nucleotide incorporation were derived from the $n+1$ bands of PAGE gel relative to the single incorporation of of ExBenziTP, BenziTP, TTP and CTP opposite $O^{6}$-CMG (A) of ExBenziTP, BenziTP, TTP and CTP opposite G (B) and of ExBenziTP, TTP and CTP opposite $O^{6}$-MeG $(\mathbf{C})$. Kobs are plotted against the nucleotide concentration and data were fit to Michaelis-Menten curves on GraphPad Prism 8. Error bars indicate standard deviations among independent replicates.

Table S1

\begin{tabular}{|cccccc|}
\hline $\mathbf{X}^{*}$ & $\mathbf{d N T P}$ & $\begin{array}{c}\mathbf{K}_{\mathbf{M}} \\
{[\boldsymbol{\mu \mathbf { M } ]}}\end{array}$ & $\begin{array}{c}\mathbf{k}_{\text {cat }} \\
{\left[\mathbf{m i n}^{-1}\right]}\end{array}$ & $\begin{array}{c}\mathbf{k}_{\text {cat }} / \mathbf{K}_{\mathbf{M}} \\
{\left[\boldsymbol{\mu} \mathbf{M}^{-1} \mathbf{m i n}^{-1}\right]}\end{array}$ & $\begin{array}{c}\mathbf{R e l a t i v e ~}^{a} \\
\mathbf{k}_{\text {cat }} / \mathbf{K}_{\mathbf{M}}\end{array}$ \\
\hline$O^{6}$-CMG & $\mathrm{C}$ & $689 \pm 104$ & 4.1 & 0.006 & 0.04 \\
& $\mathrm{~T}$ & $196 \pm 29$ & 3.8 & 0.019 & 0.13 \\
& ExBenzi & $48 \pm 7$ & 6.8 & 0.142 & 1 \\
$O^{6}-\mathrm{MeG}$ & & & & 0.02 & 0.14 \\
& $\mathrm{C}$ & $327 \pm 46$ & 6.4 & 0.12 & 0.86 \\
& $\mathrm{~T}$ & $59 \pm 18$ & 7.0 & 0.96 & 6.7 \\
\hline
\end{tabular}

${ }^{a}$ Catalytic efficiency $\left(\mathrm{k}_{\mathrm{cat}} / \mathrm{K}_{\mathrm{M}}\right)$ relative to the incorporation of ExBenzi opposite $O^{6}$-CMG ${ }^{b}$ Fold change of catalytic efficiency $\left(\mathrm{k}_{\mathrm{cat}} / \mathrm{K}_{\mathrm{M}}\right)$ relative to the incorporation of $\mathrm{C}$ opposite each DNA template

\section{Computational modelling studies}

Structures were computed with the Molecular Operating Environment software (Chemical Computing Group). Crystal structure of KlenTaq M747K with incoming ddCTP opposite template G was used (PDB ID: 5O7T).[9] The PDB file was loaded as Molecular Assembly. The ternary complex of crystal structure enzyme:template:primer was prepped by Quick Prep option. For modelling studies, incoming ddCTP was replaced by ExBenziTP or TTP by using the software Molecular Builder function; $\mathrm{G}$ was kept as $\mathrm{G}$ for modelling studies on unmodified template, or replaced by $O^{6}$-CMG for modelling studies on $O^{6}$-CMG template. After bases replacement, for energy minimizations, the potential energy of the protein was fixed at distance 4.5 to $9 \AA$ from Benzi-base pairs, and tethered at distance $>9 \AA$, by applying Amber 10 ETH force field, with 0.1 gradient. Visualization was performed in the PyMol software (Schrodinger) and images were rendered with ray 2400 . 
A

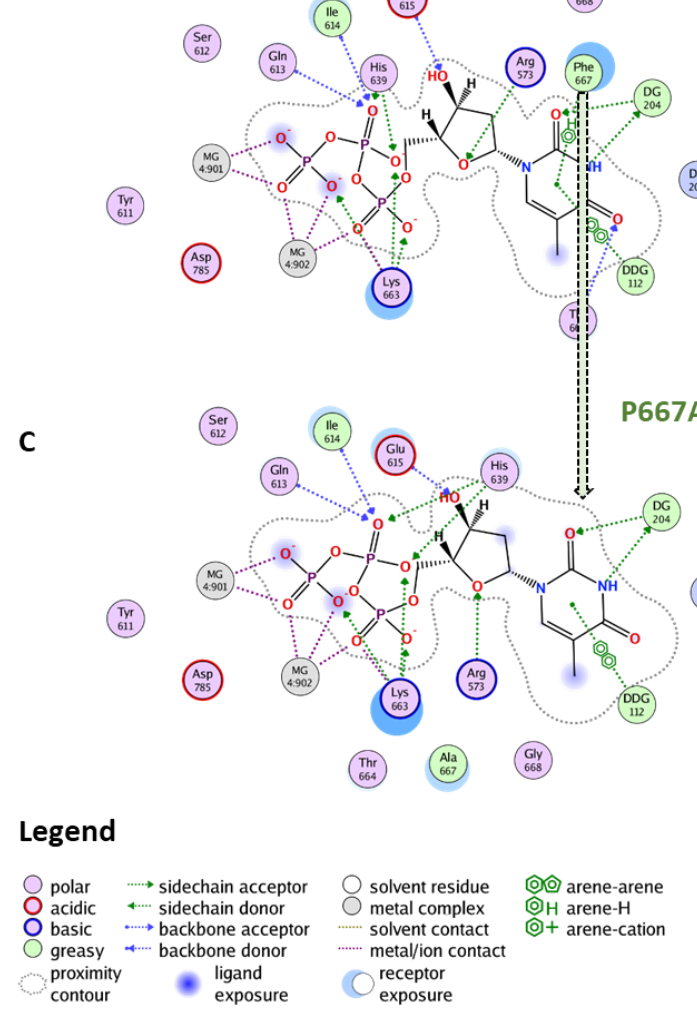

B

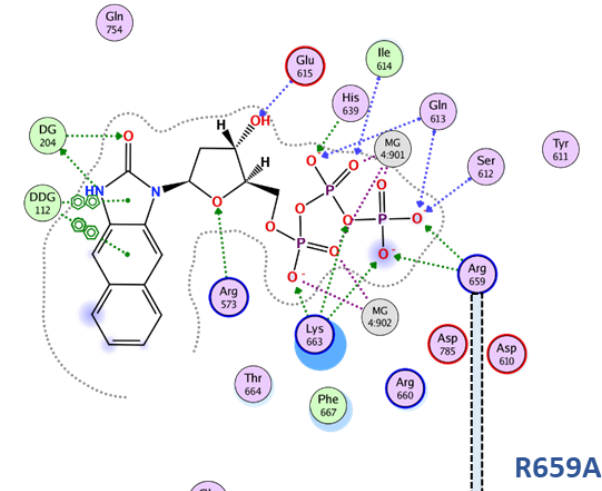

Figure S3 Modelling of ligand-protein interactions. (A) Interactions between TTP and KlenTaq M747 were modelled and an energy of $204.6 \mathrm{kcal} / \mathrm{mol}$ was calculated; (B) when Phe667 was mutated to Ala, computed energy was $203.5 \mathrm{kcal} / \mathrm{mol}$. (C) Interactions between ExBenziTP and KlenTaq M747 were modelled and an energy of 225.2 $\mathrm{kcal} / \mathrm{mol}$ was calculated; (D) when Arg659 was mutated to Ala, computed energy was $182.2 \mathrm{kcal} / \mathrm{mol}$.

\section{Linear amplification of $O^{6}$-CMG DNA}

Reaction mixtures $(20 \mu \mathrm{l})$ contained $50 \mathrm{nM}$ of KlenTaq M747K, 1x KTQ, $10 \mu \mathrm{M}$ of each dNTP, $300 \mathrm{nM}$ of 5'-6FAM-labelled $23 \mathrm{nt}$ primer and $0.5-5 \mathrm{nM}$ of $O^{6}$-CMG $28 \mathrm{nt}$ template. Reactions were performed on a T100 Thermocycler (BioRad). Final conditions included: initial denaturation step at $95{ }^{\circ} \mathrm{C}$ for $2 \mathrm{~min}$, followed by 50 cycles of $95{ }^{\circ} \mathrm{C}$ for 30 $\mathrm{s}, 42{ }^{\circ} \mathrm{C}$ for $30 \mathrm{~s}$ and $55^{\circ} \mathrm{C}$ for $30 \mathrm{~s}$, followed by a final step of elongation at $55^{\circ} \mathrm{C}$ for $3 \mathrm{~min}$. For imaging, $5 \mu 1$ of each reaction were added to $5 \mu 1$ of $2 \%$ SDS in formamide, stained with blue bromophenol, and loaded on a $15 \%$ acrylamide / $7 \mathrm{M}$ urea gel. Gels were run at $600 \mathrm{~V}$, at room temperature for 3-4 h. Gels were imaged on a ChemiDoc MP Imaging System (BioRad), by fluorescence (Ex/Em 490/520 nm).

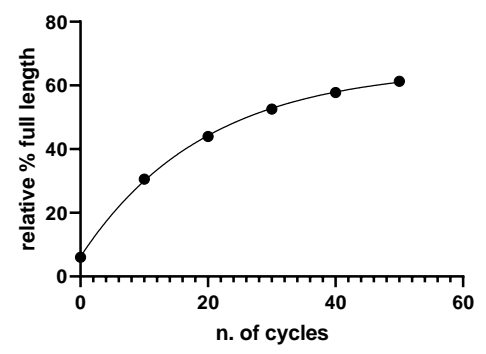

Figure S4 Amplification cycles. Reactions of linear amplifications of the $23 \mathrm{nt}$ primer complementary to $O^{6}$-CMG 28 nt template were performed by alternating $0,10,20,30,40$ or 50 cycles of melting, annealing and extension. Extension products were quantified from PAGE gels, normalized to the initial amount of primer (i.e. unreacted primer + extension product) and plotted against the number of cycles to an exponential fit with one-phase decay $\left(\mathrm{R}^{2}=0.99\right)$ on $\mathrm{GraphPad}$ Prism 8. 


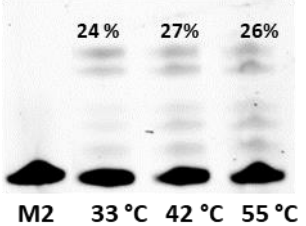

B

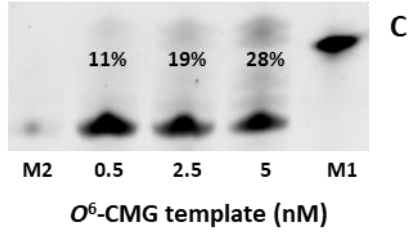

C

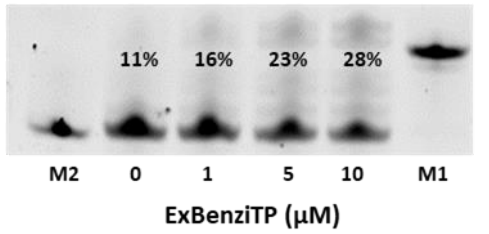

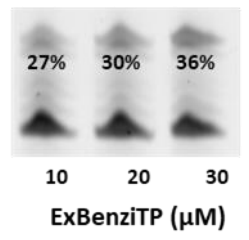

Figure S5 Conditions for the linear amplification. Reactions of linear amplifications of a 6-FAM-labelled $23 \mathrm{nt}$ primer complementary to $O^{6}$-CMG $28 \mathrm{nt}$ template were tested at varying temperatures of annealing $\left(33^{\circ} \mathrm{C}, 42^{\circ} \mathrm{C}\right.$ and $\left.55^{\circ} \mathrm{C}\right)$ and extension (not shown) to achieve the highest bypass of $O^{6}-\mathrm{CMG}$ in the presence of ExBenziTP (A). Reactions of linear amplifications of a 6-FAM-labelled 23 mer primer complementary to $O^{6}$-CMG $28 \mathrm{nt}$ template were tested at varying concentrations of initial $O^{6}$-CMG template $(0.5-5 \mathrm{nM})(\mathbf{B})$ and of ExBenziTP $(0-10 \mu \mathrm{M})(\mathbf{C})$. (M1= marker line for $28 \mathrm{nt}$; $\mathrm{M} 2=$ marker line for $23 \mathrm{nt}$ )

\section{Primer extension on $O^{6}$-CMG DNA plasmid}

Reaction mixtures $(25 \mu \mathrm{l})$ contained $50 \mathrm{nM}$ of KlenTaq M747K, 1x KTQ, $200 \mu \mathrm{M}$ of each dNTP, $200 \mathrm{nM}$ of 5'-6FAM-labelled $11 \mathrm{nt}$ primer and $10 \mathrm{ng}$ of pEGFP-W plasmid, either containing $O^{6}-\mathrm{CMG}$ or unmodified plasmid as positive control for primer extension. Reactions were performed on a T100 Thermocycler (BioRad). Final conditions included: initial denaturation step at $95^{\circ} \mathrm{C}$ for $10 \mathrm{~min}$, followed by 40 cycles of $95{ }^{\circ} \mathrm{C}$ for $1 \mathrm{~min}, 40{ }^{\circ} \mathrm{C}$ for $1 \mathrm{~min}$ and 55 ${ }^{\circ} \mathrm{C}$ for $1 \mathrm{~min}$, followed by a final step of elongation at $55{ }^{\circ} \mathrm{C}$ for $5 \mathrm{~min}$. For imaging, the whole reaction was added to 25 $\mu 12 \%$ SDS in formamide, stained with blue bromophenol (GE Healthcare, USA). Plasmid and 1kb DNA ladder (NEB, USA) were added with gel loading purple $6 x$ (NEB, USA). Samples were loaded on a $1 \%$ agarose gel. Gels were run at $80 \mathrm{~V}$, at room temperature for 90 min using 1 x TEA buffer. Gels were imaged on a ChemiDoc MP Imaging System (BioRad) by fluorescence (Ex/Em 490/520 nm).

A

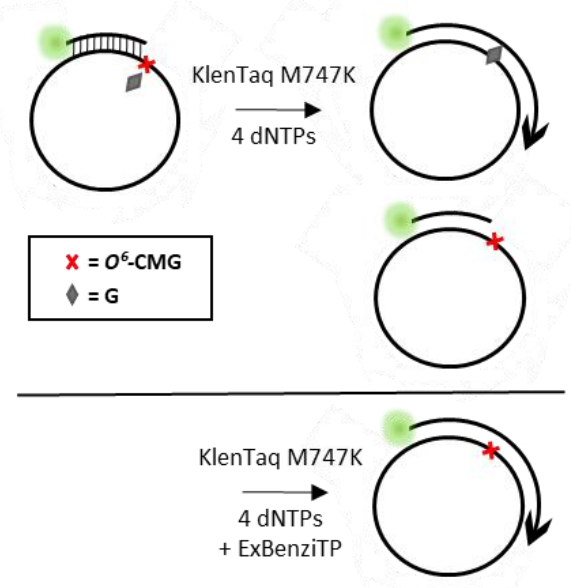

B

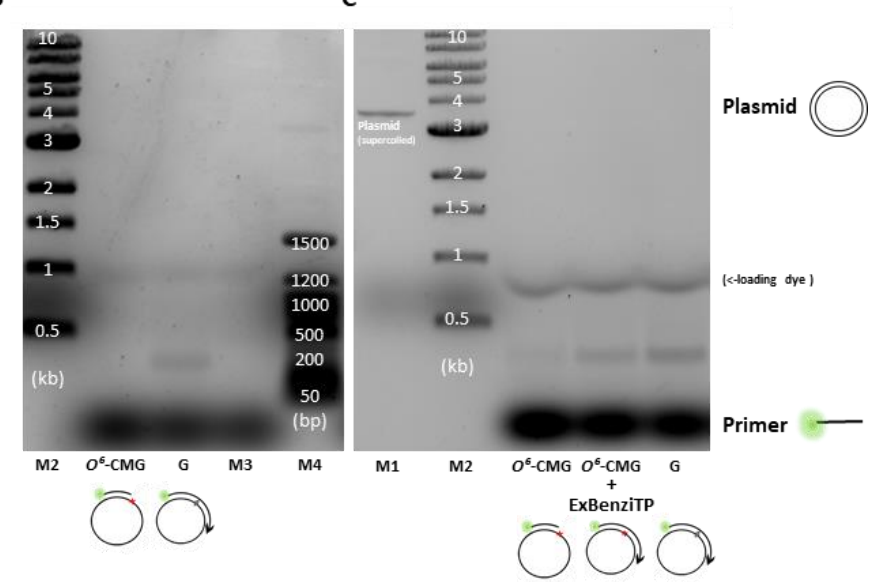

Figure S6 Primer extension past $\boldsymbol{O}^{6}$-CMG on plasmid DNA. (A) Schematic of extension of a 6-FAM $11 \mathrm{nt}$ primer past $O^{6}$-CMG or G in plasmid DNA catalyzed by KlenTaq M747K. (B) Extension of DNA primer on $O^{6}$-CMG or G plasmid DNA in the presence of all four natural dNTPS, or natural dNTPs and ExBenziTP (+ ExBenziTP). Reactions were analyzed on agarose gels and visualized by autoradiography. (C) A 50-1500 bp DNA ladder shows 11 nt primer extended around 200 bases. $(\mathrm{M} 1=$ NEB DNA ladder including DNA of 0.5-10 kb; M2 =6-FAM $11 \mathrm{nt}$ primer; M3 = NEB DNA ladder including DNA of 50-1500 bp; M4 = supercoiled plasmid, which runs faster than linear DNA; reaction samples and the 6-FAM-labelled marker M2 have been added with blue bromophenol loading; markers M1, M3 and M4 have been added with $6 x$ loading dye purple).

\section{DNA hydrolysis and sample preparation}

Amplified DNA was purified by size exclusion filtration (Bio-Spin ${ }^{\circledR}$ 6, BioRad), following the manufacturer protocol [10] and enzymatically hydrolyzed following a previously reported one-step protocol.[11] The amount of enzymes was scaled down to the size of our samples and optimized to our system, resulting in the final concentrations of $30 \mathrm{mU} / \mathrm{ml}$ of phosphodiesterase, $50 \mathrm{U} / \mathrm{ml}$ of Benzonase, $40 \mathrm{U} / \mathrm{ml}$ of alkaline phosphatase. Samples were hydrolyzed in the presence of the IS, ExBIM nucleoside (10 nM). No removal of enzymes by filtration was needed: the commonly performed step of enzyme filtration did not improve nor affect in any way the intensity of the ion signals during the final mass spectrometric analysis, while reduced the final recovery of both ExBenzi and ExBIM nucleosides. Hydrolyzed nucleosides and IS were purified by solid-phase extraction on a Strata-X cartridge ( $30 \mu \mathrm{m}$, Phenomenex, Torrance, CA). The samples were loaded on the preconditioned cartridge, washed with $1 \mathrm{~mL}$ of $20 \%$ methanol in $\mathrm{H}_{2} \mathrm{O}$, and eluted with $1 \mathrm{~mL}$ of $80 \%$ methanol $+0.1 \%$ formic acid. The eluted fractions were evaporated to dryness and stored at $-20{ }^{\circ} \mathrm{C}$ for no 
longer than one week before mass spectrometric analysis. Samples were dissolved in $10 \%$ acetonitrile and injected in the ESI-LC-MS/MS system.

Mass spectrometric method for the detection of ExBenzi nucleoside Samples were analyzed by LC-MS/MS using a nanoAcquity UPLC system (Waters; California, USA) coupled to a triple quadrupole mass spectrometer (TSQ Vantage, Thermo Fisher; Massachusetts, USA) with an electrospray ionization source. An Atlantis dC18 column (150 x $0.3 \mathrm{~mm}, 3 \mu \mathrm{m}$ - Waters; California, USA) was used at a flow rate of $10 \mu \mathrm{L} / \mathrm{min}$ and kept at a temperature of $40^{\circ} \mathrm{C}$. Prior analysis, the column was washed for $4 \mathrm{~min}$ and re-equilibrated for $9 \mathrm{~min}$. Samples were run with a gradient starting at $15 \% \mathrm{~B}$ and increasing to $90 \% \mathrm{~B}$ in $16 \mathrm{~min}$ (mobile phase A was 3\% acetonitrile in water with $0.1 \%$ formic acid, phase B was acetonitrile with $0.1 \%$ formic acid). The mass spectra were recorded in positive ionisation SRM mode with following parameters: capillary temperature, $270{ }^{\circ} \mathrm{C}$; spray voltage, $3000 \mathrm{~V}$; sheath gas pressure, 10; ion sweep gas pressure, 0; aux gas pressure, 5; Q2 CID gas pressure, $1.5 \mathrm{mTorr}$; collision gas, argon; scan width, m/z 0.01; scan time, $0.1 \mathrm{~s}$. The transitions used were $\mathrm{m} / \mathrm{z} 301 \rightarrow 185$ for ExBenzi nucleoside and $\mathrm{m} / \mathrm{z} 285 \rightarrow 169$ ExBIM nucleoside, both with Collision Energy 13 V. Xcalibur software (Thermo) was used for data acquisition and processing.

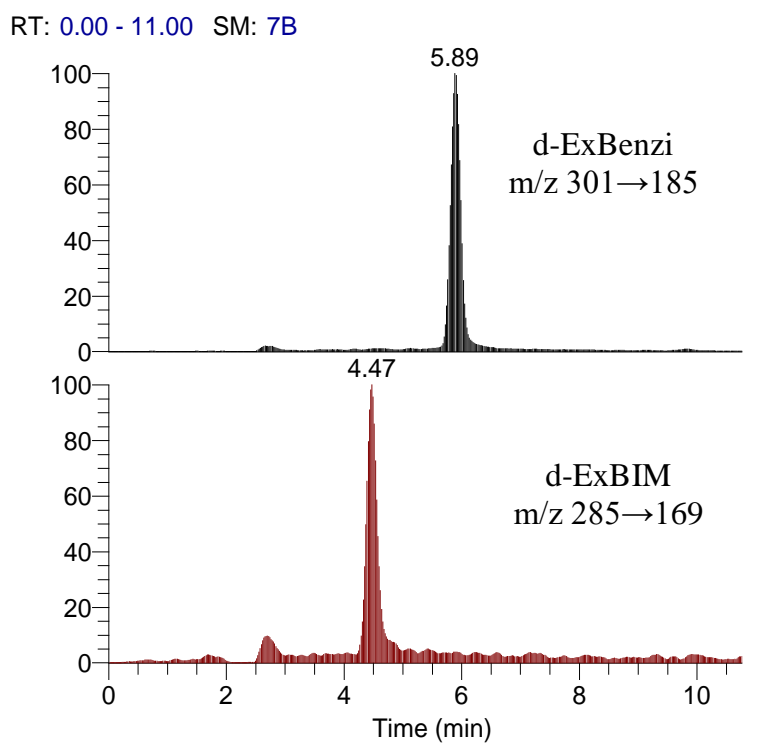

Figures S7 Mass chromatograms of ExBenzi and ExBIM nucleoside transition ions. DNA from linear amplification reactions was hydrolyzed, purified and the resulting nucleosides were separated by UPLC chromatography and ionized in a triple quadrupole mass spectrometer with electrospray ionization source and collision energy of $13 \mathrm{~V}$. ExBenzi nucleoside eluted at $5.9 \mathrm{~min}$ and was identified via the transition $\mathrm{m} / \mathrm{z} 301 \rightarrow 185$ (top). ExBIM nucleoside eluted at 4.5 min and was identified via $\mathrm{m} / \mathrm{z} 285 \rightarrow 169$ transition (bottom).

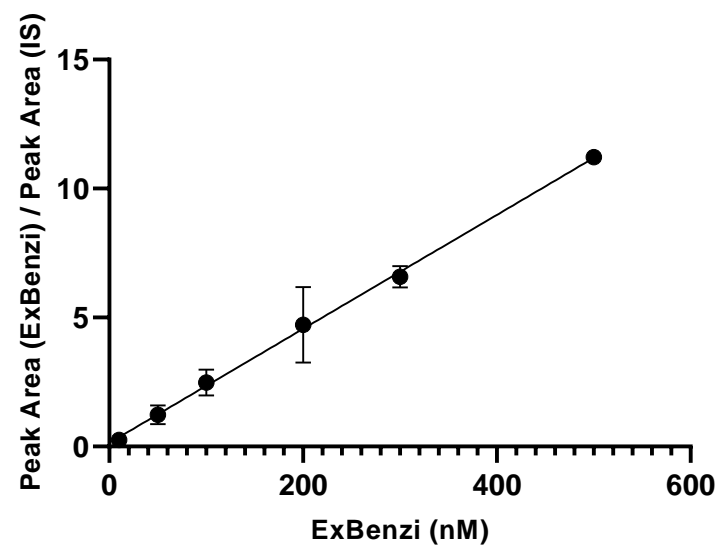

Figure S8 Calibration curve. DNA from linear amplification reactions performed in the absence of ExBenziTP were spiked with increasing concentrations of ExBenzi nucleoside (0-500 nM) and a fixed amount of ExBIM nucleoside $(10 \mathrm{nM})$, hydrolysed, purified and analysed by mass spectrometry. The peak area of ExBenzi nucleoside was normalized to the one of ExBIM nucleoside and plotted against ExBenzi nucleoside concentration on GraphPad Prism $8\left(\mathrm{R}^{2}=0.99\right)$. 


\section{REFERENCES}

[1] Raz, M. H.; Sandell, E. S.; Patil, K. M.; Gillingham, D. G.; Sturla, S. J., High Sensitivity of Human Translesion DNA Synthesis Polymerase kappa to Variation in O6-Carboxymethylguanine Structures. ACS Chem Biol 2019, 14 (2), 214-222.

[2] https://international.neb.com/protocols/2012/12/07/optimizing-restriction-endonuclease-reactions

[3] https://international.neb.com/products/t1010-monarch-plasmid-miniprep-kit\#Product\%20Information

[4] https://international.neb.com/protocols/0001/01/01/dna-ligation-with-t4-dna-ligase-m0202

[5] Trantakis I.A, Nilforoushan A., Dahlmann H.A, Stäuble C.K., Sturla S.J, In-Gene Quantification of $O^{6}$ Methylguanine with Elongated Nucleoside Analogues on Gold Nanoprobes, JACS 2016, 138, 8497-8504

[6] https://ch.promega.com/resources/protocols/technical-bulletins/0/dna-5-end-labeling-system-protocol/

[7] Boosalis M.S., Petruska J., Goodman M.F., DNA polymerase insertion fidelity. Gel assay for site-specific kinetics., J. Biol. Chem. 1987, 262, 14689-14696

[8] Gahlon H.L., Sturla S.J, Determining Steady-State Kinetics of DNA Polymerase Nucleotide Incorporation, Methods Mol Biol. 2019, 1973, 299-311

[9] Betz K., Nilforoushan A., Wyss L.A., Diederichs K., Marx A., Sturla S.J, Structural basis for the selective incorporation of an artificial nucleotide opposite a DNA adduct by a DNA polymerase, Chem. Comm. 2017, 94, 1259112714

[10] https://www.bio-rad.com/webroot/web/pdf/lsr/literature/LIT-507.pdf

[11] Quinlivan, E. P.; Gregory, J. F., DNA digestion to deoxyribonucleoside: a simplified one-step procedure. Anal Biochem 2008, 373, 2, 383-385 